\begin{tabular}{l|l|l|l|} 
VOL. 13 & NO. 2 & AUGUST 2016 & ISSN 1479-2443
\end{tabular}

\title{
MODERN
}

\section{INTELLECT UAL}

HISTORY

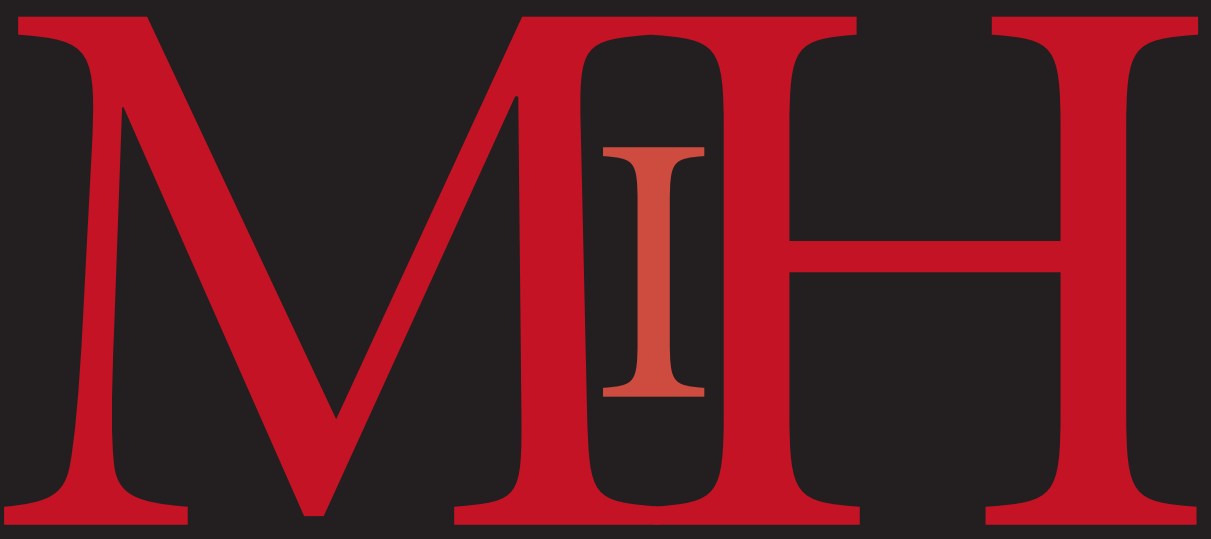




\section{Editors}

Charles Capper, Boston University, USA

Emailcapper@bu.edu

Duncan Kelly, University of Cambridge, UK

Emaildjk36@cam.ac.uk

Samuel Moyn, Harvard University, USA

Emailsmoyn@law.harvard.edu

Sophia Rosenfeld, Yale University, USA

Emailsophia.rosenfeld@yale.edu

\section{Assistant Managing Editor}

David J. Shorten

Emailmih@bu.edu

\section{Editorial Board}

David Armitage, Harvard University, usA

David Bates, University of California, Berkeley, usA

Duncan Bell, University of Cambridge, UK

Julian Bourg, Boston College, UsA

Richard Bourke, University of London, UK

Howard Brick, University of Michigan, UsA

Lawrence Buell, Harvard University, USA

Lesley Butler, Dartmouth College, usA

Deborah Coen, Columbia University, UsA

Stefan Collini, University of Cambridge, uK

Jeffrey Collins, Queen's University, Ontario, Canada

Faisal Devji, University of Oxford, UK

Dan Edelstein, Stanford University, UsA

Alexander Etkind, European University Institute, Italy

Peter Gordon, Harvard University, USA

Chris Goto-Jones, Leiden University,

The Netherlands

Cordula Grewe, University of Pennsylvania, usa

David A. Hollinger, University of California, Berkeley, usa

Joel Isaac, University of Cambridge, UK

Andrew Jainchill, Queen's University, Ontario, CANADA

Mary Kelley, University of Michigan, USA

James T. Kloppenberg, Harvard University, USA

Javed Majeed, King's College London, uK

Peter Mandler, University of Cambridge, uK

Karuna Mantena, Yale University, usA

Suzanne Marchand, Louisiana State University, USA

Federico Marcon. Princeton University, UsA

Tracie M. Matysik, University of Texas at Austin, UsA

Darrin M. McMahon, Florida State University, usA

Michael O'Brien ${ }^{\dagger}$, University of Cambridge, uK

Gabriel Paquette, Johns Hopkins University, USA

Mark A. Peterson, Berkeley, usA

Jessica Riskin, Stanford University, UsA

Camille Robcis, Cornell University, USA

John Robertson, University of Cambridge, UK

Helena Rosenblatt, City University of New York, UsA

Andrew Sartori, New York University, UsA

David Sehat, Georgia State University, USA

Celine Spector, University of Bordeaux, FRANCE

Michael Steinberg, Brown University, usA

Daniel Wickberg, The University of Texas at

Dallas, UsA

Caroline Winterer, Stanford University, usA
Modern Intellectual History publishes scholarship in intellectual and cultural history from 1650 onwards, with primary attention to Europe and the United States but also to trans-national developments that encompass the nonWest.

\section{Subscriptions \\ Modern Intellectual History (ISSN 1479-2443) is} published three times a year, in April, August and November. Three parts form a volume. The subscription price, which includes delivery by air where appropriate (but excluding VAT), of volume 13, 2016, which includes print and electronic access, is $\mathfrak{E} \mathbf{2 6 6 . 0 0}$ (US $\$ \mathbf{4 3 0 . 0 0}$ in USA, Canada and Mexico) for institutions; $\mathfrak{E}_{32.00}$ (US $\$ 49.00$ in USA, Canada and Mexico) for individuals, which includes print only. Students ordering direct from the publishers and certifying that the journal is for their personal use can subscribe to the print version at $\mathfrak{2}_{22.00}$ (US $\$ \mathbf{3 4 . 0 0}$ in USA, Canada and Mexico). The electronic-only price available to institutions is $\mathfrak{2}_{215.00}$ (US $\$ 350.00$ ). Single parts are $£ 100.00$ (US \$161.00 in USA, Canada and Mexico) plus postage. EU subscribers (outside the UK) who are not registered for VAT should add VAT at their country's rate. VAT registered members should provide their VAT registration number. Japanese prices for institutions (including ASP delivery) are available from Kinokuniya Company Ltd, P.O. Box 55, Chitose, Tokyo 156, Japan.

Articles appearing in this journal are abstracted and indexed in Historical Abstracts and America: History and Life.

This journal issue has been printed on FSC-certified paper and cover board. FSC is an independent, non-governmental, not-for-profit organization established to promote the responsible management of the world's forests. Please see www.fsc.org for information.

(C) Cambridge University Press 2016

ISSN 1479-2443 


\section{CONTENTS}

\section{Articles}

pp 299-325 Vigour, Enthusiasm and Principles: Edmund Burke's Views of European History SORA SATO

pp 327-355 The Battlefield of Metaphysics: Perpetual Peace Revisited ADAM LEBOVITZ

pp 357-386 Jazz, the Wound: Negative Identity, Culture, and the Problem of Weak Subjectivity in Theodor Adorno's Twentieth Century ERIC OBERLE

pp 387-415 The Swansong of the Mandarins: Humboldt's Idea of the University in Early Post-War Germany JOHAN ÖSTLING

pp 417-446 The Politics of Arendtian Historiography: European Federation and The Origins of Totalitarianism

WILLIAM SELINGER

\section{Essays}

pp 447-477 Liberal Dispositions: Recent Scholarship on French Liberalism MICHAEL C. BEHRENT

pp 479-505 Emancipation in the Industrial Age: Technology, Rationality, and the Cold War in Habermas's Early Epistemology and Social Theory ADELHEID VOSKUHL

pp 507-523 The Cold War as Intellectual Force Field NILS GILMAN

\section{Review Essays}

pp 525-539 Hegel and the Revolution Revisited TERENCE RENAUD

pp 541-554 Provincializing America. New and Not So New Intellectual Histories of Weimar Germany RÜDIGER GRAF

pp 555-568 Parsing Postwar American Rationality ANDREW JEWETT 